MONIKA SZYNOL

Uniwersytet Śląski, Katowice

DOI : $10.14746 /$ rie.2016.10.27

\title{
Pięć lat europejskich aspiracji Islandii - od wniosku o czlonkostwo do zawieszenia procesu akcesyjnego
}

Jeszcze w 2007 roku przeważały głosy, zgodnie z którymi: „Perspektywy przystąpienia Norwegii i Islandii do UE w najbliższej dekadzie są ograniczone. [...] Za jeden z głównych powodów należy uznać doskonałe wręcz wyniki ekonomiczne, znacznie przewyższające średnie wskaźniki na kontynencie” (Dośpiał-Borysiak, 2007, s. 134-135). W przypadku Islandii dość szybko, bo już po dwóch latach, główny argument przeciwników integracji tego państwa z Unią Europejską (wyniki ekonomiczne) stał się przyczyną złożenia przez Reykjavik wniosku o członkostwo w UE (16 lipca 2009 roku), a w dalszej kolejności - nadania statusu państwa kandydującego oraz rozpoczęcia negocjacji akcesyjnych (w 2010 roku). Co ciekawe, po pięciu latach kwestie związane z rozwojem gospodarczym doprowadziły do zawieszenia procedury akcesyjnej (w 2013 roku) i do jej zakończenia (w 2015 roku).

Celem artykułu jest analiza przyczyn zainteresowania Reykjaviku członkostwem w Unii Europejskiej, mocnych i słabych stron kandydatury Islandii (w tym porównanie tego państwa z pozostałymi krajami kandydującymi i potencjalnie kandydującymi), a także powodów, przez które proces akcesyjny został najpierw zawieszony, a następnie zakończony. Próba oceny integracji Islandii z Unią Europejską zostanie dokonana przede wszystkim na podstawie ram prawno-instytucjonalnych, które określają procedurę akcesyjną, stanu dotychczasowej współpracy pomiędzy stronami, a także działań podejmowanych przez strony od 2009 roku.

\section{Od kryzysu do wniosku akcesyjnego}

Inaczej, niż w przypadku Norwegii, która kilkukrotnie (choć bezskutecznie) angażowała się - głównie ze względu na korzyści wynikające z uczestnictwa we wspólnym rynku - w procedurę akcesji do Wspólnot Europejskich i Unii Europejskiej ${ }^{1}$, Islandia

${ }^{1}$ W związku z planami przystąpienia do Wspólnot Europejskich w latach 60. XX wieku Wielkiej Brytanii i Danii, rząd norweski (biorąc pod uwagę bliskie relacje gospodarcze z tym państwem) w 1962 roku podjął decyzję o złożeniu wniosku akcesyjnego; ten plan jednak - ze względu na załamanie negocjacji Wielkiej Brytanii i WE - został porzucony. Do jego realizacji (złożenia wniosku akcesyjnego) ponownie przystapiono w 1967 roku, Norwegia nie stała się jednak członkiem WE ze względu na wynik referendum akcesyjnego przeprowadzonego w 1972 roku (za akcesją - 46,5\%, przeciw - 53,5\% przy frekwencji 79\%). Kolejny wniosek o członkostwo Oslo złożyło w 1992 roku, podobnie jak wcześniej doszło do rozpoczęcia negocjacji akcesyjnych, ale ze względu na negatywny wynik referendum z 1994 roku (za akcesją - 47,8\%, przeciw - 52,2\% przy frekwencji 88,8\%), przystąpienie nie było możliwe. (Popławski, Starzyk-Sulejewska, 2012, passim) 
kroków takich nie podejmowała aż do końca pierwszej dekady XXI wieku. Nie oznacza to jednak, iż państwo to rozwijało się w pełnej izolacji od europejskich struktur integracyjnych. Już w 1973 roku Islandia oraz Wspólnoty Europejskie zawarły porozumienie o wolnym handlu, w 2001 roku Islandia dołączyła do strefy Schengen. Niemniej istotna jest efektywna współpraca w ramach struktur pozaunijnych - Islandia od 1949 roku należy do NATO, od 1970 roku jest członkiem Europejskiego Stowarzyszenia Wolnego Handlu, w 1994 roku dołączyła do Europejskiego Obszaru Gospodarcze$\mathrm{go}^{2}$, jest też członkiem-założycielem Światowej Organizacji Handlu. Integracja ta poskutkowała m.in. wysoką zbieżnością prawodawstwa, co finalnie znacznie wpłynęło na tempo procedury akcesyjnej.

Unijne aspiracje Islandii ściśle związane były z wybuchem kryzysu gospodarczego, który wstrząsnął sektorem bankowym i całą islandzką gospodarką.

Kryzys rozpoczął się w październiku 2008 roku spektakularnym upadkiem trzech największych banków Islandii, co doprowadziło do załamania systemu bankowego państwa. Nie był to jednak wyłącznie kryzys bankowy, ale także walutowy (wartość islandzkiej korony spadła o połowę), recesja gospodarcza oraz kryzys polityczny i społeczny (Ólafsson, 2011, s. 2). W literaturze znaleźć można wiele analiz, które opisują przyczyny kryzysu. Centralny Bank Islandii wskazuje, że wywołał go z jednej strony szybki (ale nietrwały) wzrost gospodarczy, połączony z nieprawidłowościami zarządzania makroekonomicznego w małej, otwartej i zintegrowanej gospodarce, a z drugiej strony - nazbyt dynamiczny rozwój trzech transgranicznych banków działających na podstawie tzw. europejskiego paszportu (Gudmundsson, 2011, s. 2-13). Rozwój ten wynikał z polityki prowadzonej przez islandzkie rządy na przełomie XX i XXI wieku, kiedy to priorytetem stała się szybka prywatyzacja, w tym sektora bankowego, w wyniku której wytworzyła się nowa, bogata elita, posiadająca zarówno władzę w sektorze finansowym, jak i w polityce (Boyes, 2009, passim). Co podkreśla Joachim Osiński, procesy prywatyzacyjne służyły przede wszystkim grupie 14 rodzin - tzw. islandzkiej Ośmiornicy, a „doszło z czasem do patologicznego połączenia potęgi i wpływów gospodarczych poszczególnych klanów z wpływami i znaczeniem politycznym. Prowadziło to do wykorzystywania przez osoby piastujące stanowiska premierów, ministrów i deputowanych swoich pozycji do umożliwiania związanym z nimi więzami rodzinnymi osobom przejmowania pakietów kontrolnych kolejnych prywatyzowanych firm oraz zakładania nowych firm i przedsiębiorstw będących pod «ochroną» instytucji państwowych" (Osiński, 2011, s. 21). Jednocześnie Islandczycy bardzo szybko wzbogacili się (w 2006 roku byli średnio 300\% bogatsi niż w roku 2003), a rozległy system bankowy udzielał na rynku krajowym łatwych kredytów, co doprowadziło do nadmiernego zadłużenia z jednej strony, a z drugiej - do dynamicznego wzrostu konsumpcji (Kurkliński, 2010, s. 235-236). Nasycenie rynku krajowego, a także korzystne warunki na światowym rynku finansowym, w połączeniu ze swobodą prowadzenia działalności poza Islandia, płynnością na rynku globalnym, niskimi stopami procentowymi oraz wysokim ratingiem kraju sprawiły, że „kredytowe

${ }^{2}$ W ramach EOG Islandia uczestniczy we wspólnym rynku oraz wspiera finansowo spójność społeczno-gospodarczą w Europie. Co więcej, Islandia jest również członkiem (chociaż bez prawa głosowania) wielu agencji i programów UE, związanych z przedsiębiorstwami, środowiskiem, edukacją czy badaniami. 
źródła finansowania ekspansji wydawały się niewyczerpane" (Skibińska-Fabrowska, 2013, s. 531-532). Specjalna Komisja Śledcza powołana przez islandzki parlament wymieniała wśród przyczyn kryzysu przede wszystkim: nazbyt szybką ekspansję komercyjnych banków na innych rynkach, przy wysokim ryzyku prowadzonych operacji; brak odpowiedniej reakcji władz i instytucji nadzoru na znaczny przerost systemu bankowego w stosunku do wielkości islandzkiej gospodarki; zbyt wysokie zadłużenie udziałowców banków w tych instytucjach, a także silne powiązania personalne między bankami i przedsiębiorstwami krajowymi, powodującymi wysokie ryzyko kredytowe (Hreinsson, Gunnarsson, Benediktsdóttir, 2010, s. 1-18). Wszystkie te czynniki (składające się w niektórych opiniach na „kryzys kapitalizmu” wynikający z neoliberalnej polityki gospodarczej Islandii), a także globalny kryzys finansowy, który rozpoczął się od upadku amerykańskich banków w latach 2007-2008), doprowadziły do upadku Kaupthing Bank, Landsbanki i Glitnir - największych komercyjnych banków Islandii, a następnie problemów całej islandzkiej gospodarki.

Zapaść gospodarcza doprowadziła do przyspieszonych wyborów, które odbyły się w 2009 roku. Po niemal pięćdziesięciu latach rządów centroprawicowych Partii Niepodległości i Partii Postępu, w wyniku oskarżeń tych partii o nadmierną liberalizację sektora bankowego i doprowadzenie gospodarki do kryzysu, rządy objęła socjaldemokratyczna koalicja Sojuszu i Ruchu Lewica-Zieloni (Śmieszek, 2013, s. 1-2).

Nowy rząd, na którego czele stanęła Jóhanna Sigurðardóttir, w obliczu zawirowań gospodarczych i m.in. spadku kursu korony islandzkiej względem euro o $50 \%$, podjął decyzję o złożeniu wniosku o członkostwo w Unii Europejskiej, który uznano wówczas za „najlepszą drogę do wyjścia z kryzysu i powrotu do stabilności” (Śmieszek, 2013, s. 3).

Tę decyzję z zadowoleniem przyjął również przewodniczący Komisji Europejskiej, José Manuel Barroso, który stwierdził, że ,świadczy ona o tym, że projekt integracji europejskiej jest nadal żywy oraz że Unia Europejska może być źródłem nadziei” („Polityka”).

Swój wniosek o członkostwo w Unii Europejskiej Islandia złożyła 16 lipca 2009 roku, niedługo później - 27 lipca 2009 roku - Rada zwróciła się do Komisji Europejskiej o przygotowanie opinii na temat tego wniosku. Po otrzymaniu kwestionariusza, Islandia przesłała swoją odpowiedź na niego 1 października 2009 roku.

Avis Komisji został przedstawiony 24 lutego 2010 roku. Przeanalizowano zdolność państwa ubiegającego się o członkostwo do spełnienia kryteriów kopenhaskich z 1993 roku, biorąc pod uwagę stan ówczesny oraz perspektywę średnioterminową (określoną na 3 lata), nie wskazując jednocześnie daty przyszłej akcesji (Communication). Komisja Europejska uznała, iż Islandia spełnia (z pewnymi zastrzeżeniami ${ }^{3}$ ) kryterium polityczne, spełnia kryterium gospodarcze ( $\mathrm{w}$ analizie wzięto pod uwagę problem kry-

${ }^{3}$ Komisja Europejska dostrzegła ryzyko konfliktu interesów publicznych ze względu na bliskie relacje pomiędzy islandzkimi elitami politycznymi oraz światem biznesu (szczególnie biorąc pod uwagę niską liczbę ludności oraz lokacyjną izolację Islandii). Jednocześnie wskazano, że w konsekwencji kryzysu bankowego powstały specjalne komisje śledcze, których zadaniem było zbadanie i ściganie możliwych przestępstw w kontekście upadku banków, które - po niezbędnym wzmocnieniu tego mechanizmu - powinny przeciwdziałać wspomnianemu konfliktowi interesów (Communication). 
zysu gospodarczo-walutowego, który doprowadził do głębokiej recesji; za warunek spełnienia kryterium uznano kontynuację rozpoczętych reform, co w średnim okresie wpłynąć miało na zdolność Islandii do sprostania warunkom konkurencji rynkowej wewnątrz UE), częściowo spełnia kryterium prawne, jednak wzmożone działania w niektórych obszarach są niezbędne do jego całkowitego spełnienia ${ }^{4}$. Jednocześnie wskazano, że akcesja Islandii będzie miała ograniczony wpływ na Unię Europejską i nie wpłynie na zdolność UE do pogłębiania swojego rozwoju.

Rzeczywiście - w szczególności na tle innych państw, które wówczas ubiegały się o członkostwo w Unii Europejskiej, posiadając status kandydujących lub potencjalnie kandydujących - Islandia postrzegana była niemalże jako „kandydat idealny”, państwo wysoko rozwinięte, nieobarczone zaszłościami historycznymi, nieskonfliktowane z poszczególnymi państwami członkowskimi. Kolejnym atutem miał być niewielki wpływ potencjalnej akcesji Islandii na sprawy wewnętrzne UE, jeśli już, to spodziewano się raczej (po wyjściu tego kraju z kryzysu), że wpływ ten będzie pozytywny (przede wszystkim finansowo) ${ }^{5}$.

Na przełomie pierwszej i drugiej dekady XXI wieku o członkostwo w Unii Europejskiej ubiegały się (oprócz Islandii): Chorwacja (akcesja 1 lipca 2013 roku), Była Jugosłowiańska Republika Macedonii, Czarnogóra, Serbia oraz Turcja (państwa, które otrzymały statusy państw kandydujących nadane przez Radę Europejską po rekomendacji Komisji Europejskiej), wśród potencjalnie kandydujących wymieniano Albanię (w 2014 roku otrzymała status państwa kandydującego), Bośnię i Hercegowinę oraz Kosowo ${ }^{6}$. Podkreślić należałoby zróżnicowanie państw, które wówczas starały się (i wciąż starają) o członkostwo w UE; zróżnicowanie nie tylko pod względem powierzchni terytorialnej czy liczby ludności oraz tempa integracji europejskiej (dynamicznego w przypadku Islandii i niespiesznego w odniesieniu do Turcji), ale także różnorodności motywów nawiązania bliższych relacji z Unią. O ile perspektywa rozszerzenia o państwa Bałkanów Zachodnich porównywana jest do starań państw środkowoeuropejskich $\mathrm{z}$ lat 90 . XX wieku, a UE odgrywa w tym procesie przede wszystkim funkcję stabilizującą transformację systemową, przemiany demokratyczne i budowę (lub wzmacnianie) wolnego rynku, tak innymi cechami charakteryzują się motywy pozostałych kandydatów - Islandii i Turcji.

${ }^{4}$ W kontekście spełniania kryterium prawnego, w opinii wskazano, że: a) Islandia posiada zadowalające osiaggnięcia w wypełnianiu zobowiązań wynikających z członkostwa w Europejskim Obszarze Gospodarczym; b) przepisy dotyczące rynku wewnętrznego wprowadzone do prawa krajowego są na tym samym poziomie, jak w państwach członkowskich UE; c) Islandia jest dobrze przygotowana do spełnienia kryterium prawnego w obszarach pokrywających się z obszarami działalności EOG; d) konieczne będą dodatkowe działania, których celem będzie wypełnienie kryterium prawnego w następujących obszarach: rybołówstwo, rolnictwo i rozwój wsi, środowisko, swobodny przepływ kapitału, usługi finansowe, unia celna, podatki, statystyka, bezpieczeństwo żywności, polityka weterynaryjna i fitosanitarna, polityka regionalna i koordynacja instrumentów strukturalnych, kontrola finansowa. (Communiaction).

${ }^{5} \mathrm{~Np}$. od 2004 roku Islandia przekazywała wsparcie finansowe najbiedniejszym regionom nowych państw członkowskich poprzez Instrument Finansowy EOG. (Dośpiał-Borysiak, 2007, s. 134).

${ }^{6}$ Użycie tej nazwy nie wpływa na stanowiska w sprawie statusu Kosowa i jest zgodne z rezolucją Rady Bezpieczeństwa ONZ 1244/1999 oraz z opinią Międzynarodowego Trybunału Sprawiedliwości na temat ogłoszenia przez Kosowo niepodległości. 
Różny był też stopień spełnienia kryteriów kopenhaskich przez wcześniej wymienione państwa. Biorąc pod uwagę fakt, iż brakuje opracowanych wskaźników oraz metodologii pomiaru stopnia ich spełnienia, dywersyfikację kandydatów można przedstawić przy pomocy rankingów i indeksów przygotowywanych corocznie przez międzynarodowe ośrodki analityczno-badawcze. W odniesieniu do kryterium politycznego warto odwołać się chociażby do Indeksu Demokracji opracowanego od 2006 roku przez Economist Intelligence Unit (jednostkę badawczą związaną z tygodnikiem „The Economist”, opisującą stan demokracji w 167 państwach świata) czy sporządzanych regularnie od 1972 roku raportów Freedom in the World, przygotowywanych przez amerykańską organizację Freedom House (założoną w 1941 roku przez Wendella Wilkiego i Eleanore Roosevelt, która ocenia przestrzeganie i ochronę praw politycznych i swobód obywatelskich w poszczególnych krajach). Poniżej dla przykładu przedstawiono pozycje zajęte przez państwa kandydujące i potencjalnie kandydujące we wskazanych rankingach w latach 2009 (2010) i 2014.

Tabela 1

Państwa kandydujące i potencjalnie kandydujące w Indeksie Demokracji 2010 i 2014 oraz wedlug raportu Freedom in the World 2009 i 2014

\begin{tabular}{|c|c|c|c|c|c|c|}
\hline & \multicolumn{4}{|c|}{ Democracy Index } & \multirow{2}{*}{\multicolumn{2}{|c|}{ Freedom in the World }} \\
\hline & \multicolumn{2}{|r|}{2010} & \multicolumn{2}{|r|}{2014} & & \\
\hline & pozycja & suma/10 pkt & pozycja & suma/10 pkt & 2009 & 2014 \\
\hline \multicolumn{7}{|c|}{ Demokracje pelne } \\
\hline Islandia & 2 & 9,80 & 3 & 9,58 & wolny & wolny \\
\hline \multicolumn{7}{|c|}{ Demokracje wadliwe } \\
\hline Chorwacja & 53 & 6,81 & 50 & 6,93 & wolny & wolny \\
\hline Serbia & 65 & 6,33 & 56 & 6,71 & wolny & wolny \\
\hline Czarnogóra* & 68 & 6,27 & 77 & 5,94 & $\begin{array}{c}\text { częściowo } \\
\text { wolny }\end{array}$ & wolny \\
\hline Macedonia & 73 & 6,16 & 71 & 6,25 & $\begin{array}{l}\text { częściowo } \\
\text { wolny }\end{array}$ & $\begin{array}{c}\text { częściowo } \\
\text { wolny }\end{array}$ \\
\hline \multicolumn{7}{|c|}{ Systemy hybrydowe } \\
\hline Albania & 84 & 5,86 & 88 & 5,67 & $\begin{array}{c}\text { częściowo } \\
\text { wolny }\end{array}$ & $\begin{array}{c}\text { częściowo } \\
\text { wolny }\end{array}$ \\
\hline Turcja & 89 & 5,73 & 98 & 5,12 & $\begin{array}{l}\text { częściowo } \\
\text { wolny }\end{array}$ & $\begin{array}{c}\text { częściowo } \\
\text { wolny }\end{array}$ \\
\hline Bośnia i Hercegowina & 94 & 5,32 & 103 & 4,78 & $\begin{array}{l}\text { częściowo } \\
\text { wolny }\end{array}$ & $\begin{array}{c}\text { częściowo } \\
\text { wolny }\end{array}$ \\
\hline Kosowo & $b / d$ & $b / d$ & $b / d$ & $b / d$ & bez wolności & $\begin{array}{c}\text { częściowo } \\
\text { wolny }\end{array}$ \\
\hline
\end{tabular}

* Czarnogóra w 2014 roku została zaliczona do grupy państw o systemie hybrydowym.

Źródło: Opracowanie własne na podstawie: „, The Economist” - Intelligence Unit, Democracy Index 2010. Democracy in retreat. A report from the Economist Intelligence Unit, London 2011, www.eiu.com, 15.05.2015; „The Economist” - Intelligence Unit, Democracy Index 2014. Democracy and its discontents. A report from the Economist Intelligence Unit, London 2015, www.eiu.com, 15.05.2015; Freedom House, 2009 Freedom in the World, www.freedomhouse.org, 15.05.2015; Freedom House, 2010 Freedom in the World, www.freedomhouse.org, 15.05.2015.

Z grona państw kandydujących i potencjalnie kandydujących najlepiej zaprezentowała się Islandia, która osiagnęła lepszy wynik nie tylko od pozostałych kandyda- 
tów, ale i od wielu państw członkowskich UE. Wysoki poziom rozwoju demokracji, a jednocześnie zbieżność ze standardami unijnymi wpłynęły na szybkie tempo procesu akcesyjnego w odniesieniu do tego państwa.

Analogicznego porównania można dokonać w odniesieniu do spełnienia kryterium gospodarczego, wykorzystując np. raport publikowany przez „The Wall Street Journal" i Heritage Foundation - Wskaźnik Wolności Ekonomicznej (Index of Economic Freedom), który opisuje i ocenia ograniczenia, przepisy i zakres stosowania przymusu przez aparat władzy w sferze gospodarki w 178 państwach świata. W poniższej tabeli zaprezentowano przykładowe wyniki osiagnnięte przez państwa kandydujące i potencjalnie kandydujące do UE z lat 2009 i 2014.

Tabela 2

Państwa członkowskie Unii Europejskiej, państwa kandydujące i potencjalnie kandydujące według Wskaźnika Wolności Ekonomicznej 2009 i 2014

\begin{tabular}{|c|c|c|c|c|}
\hline & \multicolumn{2}{|c|}{2009} & \multicolumn{2}{|c|}{2014} \\
\hline & pozycja & suma/100 pkt & pozycja & suma/100 pkt \\
\hline \multicolumn{5}{|c|}{ W zasadzie wolne } \\
\hline Islandia & 14 & 75,9 & 23 & 72,4 \\
\hline \multicolumn{5}{|c|}{ Umiarkowanie wolne } \\
\hline Albania & 62 & 63,7 & 54 & 66,9 \\
\hline Turcja & 75 & 61,6 & 64 & 64,9 \\
\hline Macedonia & 78 & 61,2 & 43 & 68,6 \\
\hline Czarnogóra & 94 & 58,2 & 68 & 63,6 \\
\hline \multicolumn{5}{|c|}{ W zasadzie bez wolności } \\
\hline Serbia & 109 & 56,6 & 95 & 59,4 \\
\hline Chorwacja & 116 & 55,1 & 87 & 60,4 \\
\hline Bośnia i Hercegowina & 134 & 53,1 & 101 & 58,4 \\
\hline Kosowo & $\mathrm{b} / \mathrm{d}$ & $\mathrm{b} / \mathrm{d}$ & $\mathrm{b} / \mathrm{d}$ & $\mathrm{b} / \mathrm{d}$ \\
\hline
\end{tabular}

Źródło: Opracowanie własne na podstawie: Hertigage Foundation, 2009 Index of Economic Freedom, www.heritage.org, 15.05.2015; Heritage Foundation, 2014 Index of Economic Freedom, www.heritage. org, 15.05.2015.

Również w tym rankingu Islandia osiągnęła znacznie lepszy wynik od reszty państw kandydujących i potencjalnie kandydujących, znajdując się m.in. w grupie państw członkowskich UE. Na pozycję uzyskaną przez Reykjavik rzutował przede wszystkim kryzys gospodarczy oraz metody rozwiązania go, jednak - jak już wcześniej podkreślono - kontynuacja podjętych reform była wystarczająca dla Komisji Europejskiej, by uznać kryterium gospodarcze w przypadku Islandii za wypełnione.

Kryterium prawne, określające w największej mierze zdolność państwa do przyjęcia dorobku prawnego UE (jak też zresztą kryteria polityczne i gospodarcze), weryfikowane jest poprzez raporty postępów, sporządzane corocznie przez Komisję Europejską. Analiza spełnienia tego kryterium oparta jest o około 30 tematów, swoim zakresem odpowiadających rozdziałom negocjacyjnym. Ocena dokonywana jest na podstawie decyzji, przyjętych przepisów i wdrożonych przez państwo środków w tych obszarach. W trakcie opiniowania postępów osiagniętych w poszczególnych obszarach $\mathrm{w}$ danych okresach sprawozdawczych oraz ogólnego podsumowania poziomu państw kandydujących, Komisja Europejska korzysta głównie z informacji zebranych 
i przeanalizowanych przez siebie. Informacje te pochodzą z różnych źródeł: od rządów państw kandydujących i potencjalnie kandydujących, państw członkowskich UE, Parlamentu Europejskiego, organizacji międzynarodowych i pozarządowych. Mimo że ta część raportu opiera się głównie na stwierdzeniach: „mały postęp”, „niewielki postęp”, „średni postęp” lub ,pewien postęp”, porównując w ten sposób uzyskane przez państwa kandydujące i potencjalnie kandydujące oceny, największą zbieżność z acquis communautaire - co już wcześniej podkreślano - odnotowano w przypadku Islandii.

Nie mniej istotnym kryterium w procesie akcesyjnym, prócz trzech kryteriów dotyczących bezpośrednio państw ubiegających się o członkostwo, jest warunek dotyczący Unii Europejskiej, a dokładniej - jej zdolności integracyjnych. Zdolności absorpcyjne ważne są zarówno dla samej UE, jak i poszczególnych państw kandydujących (Conclusions). Rozwinięcie tego kryterium można znaleźć m.in. w komunikacie Komisji do Parlamentu Europejskiego i Rady - „Strategia rozszerzenia i najważniejsze wyzwania w okresie 2006-2007 wraz ze sprawozdaniem specjalnym dotyczącym zdolności UE do przyjmowania nowych państw”. W komunikacie zaznaczono, iż zdolności integracyjne zależą od dwóch czynników: utrzymania tempa działań w celu zacieśniania i intensyfikacji integracji europejskiej poprzez zagwarantowanie ciąłości funkcjonowania UE oraz należyte sprawdzenie, czy potencjalni kandydaci w dniu akcesji są zdolni do przyjęcia wynikających z członkostwa obowiązków i spełniają pozostałe kryteria (Komuni$k a t$ ). Temat zdolności Unii Europejskiej do przyjęcia nowych członków przy zachowaniu dynamiki integracji europejskiej podjął także Parlament Europejski. Za podstawowe czynniki zdolności integracyjnych UE uznano czynniki: instytucjonalne - instytucje UE, ich legalność, demokratyczny i skuteczny proces decyzyjny (Rezolucja legislacyjna); finansowe - zasoby finansowe, ogólny wkład do gospodarczej i społecznej spójności i polityczne - zdolności do osiagania politycznych celów (Rezolucja Parlamentu). Ważną kwestią pozostaje również poparcie opinii publicznej dla procesu rozszerzenia.

Akcesja Islandii - zgodnie z przedstawioną przez Komisję Europejską opinią - miała mieć ograniczony wpływ na przyszłość Unii Europejskiej. W porównaniu do innych państw kandydujących i potencjalnie kandydujących, poparcie obywateli UE dla członkostwa Reykjaviku było największe ${ }^{7}$.

Jednocześnie stwierdzić trzeba, że na tle tychże państw Islandia najmniej była obciążona problemami, które oddziaływałyby na wewnętrzną spoistość Unii. Wśród nich wymienić można:

${ }^{7}$ W 2008 roku największym poparciem dla perspektywy członkostwa cieszyła się Islandia średnio $71 \%$ obywateli UE opowiedziało się za przystapieniem, z kolei 16\% przeciw niemu. Największe poparcie zostało wskazane w Danii (94\%), Estonii i na Cyprze (93\%), Szwecji (89\%), Finlandii (88\%), Holandii i Słowenii (87\%), Grecji (86\%), Luksemburgu (80\%), Słowacji (79\%), Polsce (78\%), Belgii, Litwie i Bułgarii (77\%), Czechach (76\%), Łotwie, Rumunii i na Węgrzech (74\%), Niemczech (73\%), Francji (72\%) oraz Hiszpanii (70\%). Islandia najwięcej przeciwników znalazła z kolei w Austrii (28\%) oraz w Portugalii i Wielkiej Brytanii (po 25\%). Zupełnie odmienne było zdanie obywateli UE o możliwości przystąpienia Turcji - ponad połowa respondentów (55\%) opowiedziała się przeciw temu państwu w Unii, za akcesją średnio opowiedziało się $31 \%$ badanych. W odniesieniu do pozostałych państw kandydujących i potencjalnie kandydujących wyniki badania przedstawiały się następująco: Była Jugosłowiańska Republika Macedonii - 40\% za, 43\% przeciw; Albania - 34\% za, 51\% przeciw; Bośnia i Hercegowina - 40\% za, 44\% przeciw; Serbia i Czarnogóra (ostatnie badanie przeprowadzono w 2005 roku) - 39\% za, 44\% przeciw (Public). 
- słabości instytucjonalne wynikające z procesu transformacji w państwach kandydujących i potencjalnie kandydujących - szczególnie państwa bałkańskie borykają się z problemami typowymi dla państw o młodej i dopiero stabilizującej się demokracji, jak np.: niedociągnięcia w funkcjonowaniu instytucji demokratycznych (m.in. nieprawidłowości w przeprowadzaniu wyborów widoczne w Byłej Jugosłowiańskiej Republice Macedonii oraz Czarnogórze, gdzie wybory nie zostały ujednolicone z konstytucją); nieustabilizowany rozdział władz, szczególnie w odniesieniu do władzy sądowniczej (widoczne w przypadku Czarnogóry i Serbii); zastrzeżenia odnośnie do niezależności i skuteczności sądownictwa; słabość administracji publicznej, jej podatność na wpływy polityczne, brak profesjonalizacji i przejrzystości; niedostateczna dbałość o ochronę praw podstawowych, wolność słowa, wolność mediów, niedociagnięcia w zakresie polityki antydyskryminacyjnej; słabość społeczeństwa obywatelskiego; korupcja;

- spory dwu- i wielostronne z udziałem państw kandydujących i potencjalnie kandydujących - np. konflikt macedońsko-grecki dotyczący nazwy państwa (Muś, 2011, s. 59-62), konflikt turecko-cypryjski (Adamczyk, 1997, passim) czy konflikt serbsko-albański o Kosowo (Gibas-Krzak, 2009, s. 181 i nast.);

- wyzwania dla bezpieczeństwa narodowego i międzynarodowego - niestabilność regionu Bałkanów Zachodnich, która objawia się licznymi konfliktami terytorialnymi oraz etnicznymi (angażującymi nie tylko wybrane państwa sąsiedzkie, poszczególne państwa członkowskie UE, ale też całą społeczność międzynarodowa); wyzwania związane z akcesją Turcji (z jednej strony zbliżenie się do kluczowych światowych konfliktów, wzrost wydatków na bezpieczeństwo i ochronę granic, zagrożenie terroryzmem kurdyjskim, wielka migracja z Turcji; z drugiej strony Turcja mogłaby się stać silnym sojusznikiem $\mathrm{w}$ walce $\mathrm{z}$ terroryzmem międzynarodowym i proliferacją broni masowego rażenia, a także stabilizacji sytuacji w regionie, szansa na wzmocnienie bezpieczeństwa energetycznego państw UE);

- zróżnicowanie w poziomie rozwoju gospodarczego pomiędzy państwami członkowskimi UE a państwami kandydującymi i potencjalnie kandydującymi - np. w 2012 roku PKB na mieszkańca według parytetu siły nabywczej wyrażony w wartości euro wynosił: Czarnogóra - 5 385, Macedonia - 3 651, Serbia - 4 100, Turcja - 8 223, Albania - 3 344, Bośnia i Hercegowina - 3 419, Kosowo - 2 650, Islandia - 33 000, przy średniej unijnej EU-27 - 25700 (Candidate);

- skalę bezrobocia w przypadku państw członkowskich oraz państw kandydujących i potencjalnie kandydujących do członkostwa - np. w 2013 roku stopa bezrobocia wynosiła: Czarnogóra - 17,1\%, Macedonia - 32,1\%, Serbia - 20,0\%, Turcja - $8,7 \%$, Albania - 14,8\%, Bośnia i Hercegowina - 43,0\%, Kosowo - 30,9\%, Islandia $-5,4 \%$, przy średniej unijnej UE-28 - 10,8\% (Key); wysokie bezrobocie w państwach kandydujących i potencjalnie kandydujących rodzi obawy związane z kolejną falą migracji zarobkowej obywateli tych państw do krajów, które już są członkami UE, co mogłoby doprowadzić do zakłóceń rynku pracy UE;

- kryterium państwa europejskiego i dylemat „europejskości” - przypadek Turcji, dotyczący z jednej strony geografii (pod względem położenia geograficznego Turcja zaliczana jest do Europy Południowo-Wschodniej i Południowo-Zachodniej Azji, z tym że część zachodu kraju - Bosfor, stanowiący „pomost między zacho- 
dem i wschodem" - geograficznie jest częścią Europy; ta część stanowi jednak zaledwie 3\% powierzchni Turcji), z drugiej czynników kulturowych (w literaturze Turcja nazywana jest ,krajem rozdartym” pomiędzy fragmentem cywilizacji Zachodu, jak to widzą elity, a niezgodną z tym stwierdzeniem dużej części społeczeństwa) (Huntington, 1993, s. 30 i nast.);

- perspektywa i powszechne obawy przed islamizacją Europy - struktura wyznaniowa państw, które ubiegają się o członkostwo w UE, jest bardziej zróżnicowana niż w państwach członkowskich; największe kontrowersje budzi liczba wyznawców islamu - ta największa jest w Turcji (99,8\% wierzących), chociaż islam obecny jest także na Bałkanach Zachodnich (Macedonia - 33,3\%, Czarnogóra - 19,1\%, Serbia - 3,1\%, Albania - 56,7\%, Bośnia i Hercegowina - 40\%) (World); nieprzychylność wobec możliwości przystapienia Turcji oraz państw bałkańskich do Unii Europejskiej może zatem, przynajmniej częściowo, wynikać z lęków przed konsekwencjami integracji z państwami o tak wysokim odsetku wyznawców islamu (szczególnie w przypadku Turcji) i poczucia odmienności kulturowo-religijnej, wzmacnianej powtarzanymi stereotypami dotyczącymi mniejszości muzułmańskich w państwach UE, ich marginalizacją i stygmatyzacją; Islandia pod względem wyznania nie różni się znacząco od innych państw europejskich - dominuje protestantyzm (przynależność do Islandzkiego Kościoła Luterańskiego deklaruje 76,2\% obywateli), wyznawcami Kościoła rzymskokatolickiego jest 3,4\% mieszkańców wyspy (World).

Islandia, ściśle współpracująca z Unią Europejską i jej państwami członkowskimi, postrzegana głównie przez pryzmat wysokiego poziomu rozwoju gospodarczego oraz spełniania wysokich standardów demokratycznych, co zbliżało ją do państw jednoczącej się Europy (a jednocześnie oddalało od pozostałych państw kandydujących i potencjalnie kandydujących), uzyskała od Komisji Europejskiej pozytywną opinię dotyczącą swojego wniosku o członkostwo oraz rekomendację do rozpoczęcia negocjacji akcesyjnych (Communication).

Niemniej decyzja ta nie była jednoznaczna $\mathrm{z}$ brakiem jakichkolwiek potencjalnych kwestii spornych w trakcie integracji Islandii z Unią Europejską.

Podstawowym problemem w stosunkach wzajemnych jest rybołówstwo, które - szczególnie po tzw. boomie śledziowym z lat 60 . XX wieku - jest jednym z filarów islandzkiej gospodarki (zatrudniającym blisko co dziesiątego Islandczyka i stanowiącym ponad 40\% eksportu). W dyspozycji Islandii znajduje się strefa połowu wielkości 760000 km² o głębokości 200 mil morskich, w której znajdują się największe zasoby rybne Atlantyku. Zgodnie z prawodawstwem Unii Europejskiej, wody te - w przypadku akcesji - nie tylko stałyby się wodami UE (co jest jednoznaczne z wpuszczaniem na nie kutrów innych państw członkowskich), ale Islandia musiałaby również stosować się do ustalonych kwot połowowych. W trakcie dalszych negocjacji podkreślano co prawda, że Islandia mogłaby stać się wzorem zrównoważonego rybołówstwa (premier Sigmundur Gunnlaugsson twierdził, że ,chcielibyśmy pomóc Unii w osiagnięciu podobnych rezultatów w zakresie zarządzania zasobami rybnymi. Jeżeli UE będzie chronić swoje zasoby rybne tak jak Islandia, to wartość europejskiego rybołówstwa ogromnie wzrośnie") (Barroso), pamiętać jednak trzeba, że w trakcie negocjacji najważniejszych umów handlowych przez Islandię starano się maksymalnie zabezpieczyć 
wolny handel w sektorze rybnym przy jednoczesnej wyłączności połowów (DośpiałBorysiak, 2007, s. 123-124).

Jako kolejne ognisko zapalne zidentyfikować należy spór o Icesave. W trakcie kryzysu z 2008 roku upadł również bank internetowy Icesave, który działał także w Wielkiej Brytanii i Holandii. W wyniku załamania całego systemu bankowego Islandii, narodowy system zagwarantowania depozytów nie był zdolny do spłaty wszystkich obciążeń - rządy Wielkiej Brytanii i Holandii samodzielnie pokryły straty swoich obywateli, zwracając się następnie do rządu Islandii o zwrot poniesionych kosztów wraz z odsetkami. Ze względu na niemożność rozwiązania sprawy, trafiła ona do Trybunału EFTA (Śmieszek, 2013, s. 2-5).

\section{Od statusu państwa kandydującego do negocjacji akcesyjnych}

Rada Europejska w trakcie szczytu w czerwcu 2010 roku przyjęła zalecenie Komisji Europejskiej, potwierdziła, iż Islandia spełnia kryteria ustalone w 1993 roku w Kopenhadze i potwierdziła status państwa kandydującego, jednocześnie rekomendując rozpoczęcie negocjacji akcesyjnych (Konkluzje).

Pierwsza międzyrządowa konferencja akcesyjna odbyła się 27 lipca 2010 roku, natomiast 15 listopada 2010 roku rozpoczął się pierwszy etap negocjacji - screening, czyli przegląd prawa obowiązującego w państwie kandydującym pod kątem jego zgodności z regulacjami obowiązującymi w Unii Europejskiej. Za dokonanie tego przeglądu odpowiedzialna jest Komisja Europejska, która sporządza także raport dotyczący zgodności prawa krajowego z europejskim. Dzięki screeningowi możliwe jest przygotowanie wyjściowych stanowisk negocjacyjnych zarówno państwa kandydującego, jak i państw członkowskich (Barcz, 2009, s. 91). Przegląd zakończył się 20 czerwca 2011 roku.

Negocjacje merytoryczne, których celem jest najpierw ustalenie rozbieżności między dorobkami prawnymi stron, a następnie - określenie sposobu i treści koniecznych zmian, rozpoczęły się 27 czerwca 2011 roku. Przyjęte ramy negocjacyjne określiły 35 obszarów rozmów: swobodny przepływ towarów; swobodny przepływ pracowników; swobodny przepływu usług; swobodny przepływ kapitału; zamówienia publiczne; prawo spółek; prawo własności intelektualnej; polityka konkurencji; usługi finansowe; społeczeństwo informacyjne i media; rolnictwo i rozwój wsi; bezpieczeństwo żywności, polityka weterynaryjna i fitosanitarna; rybołówstwo; polityka transportowa; energia; podatki; polityka gospodarcza i walutowa; statystyka; polityka społeczna i zatrudnienie; przedsiębiorstwa i polityka przemysłowa; sieci transeuropejskie; polityka regionalna i koordynacja instrumentów strukturalnych; sądownictwo i prawa podstawowe; sprawiedliwość, wolność i bezpieczeństwo; nauka i badania; edukacja i kultura; środowisko; ochrona zdrowia i konsumentów; unia celna; stosunki zewnętrzne; polityka zagraniczna, bezpieczeństwa i obronna; kontrola finansowa; finanse i budżet; instytucje; wszelkie pozostałe zagadnienia (Iceland).

W trakcie konferencji rozpoczynającej negocjacje merytoryczne otwarto cztery rozdziały negocjacyjne, a dwa tymczasowo zamknięto (co oznacza, iż stanowiska stron zostały wystarczająco wyjaśnione, są akceptowalne, jednak przed ostatecznym zakoń- 
czeniem negocjacji możliwe jest powrócenie do obszarów tymczasowo zamkniętych w myśl zasady „nic nie jest ostatecznie zamknięte, póki wszystko nie jest ostatecznie zamknięte") (Barcz, 2009, s. 94).

Kolejne konferencje odbywały się: 19 października 2011 roku (dwa rozdziały otwarto i tymczasowo zamknięto), 12 grudnia 2011 roku (pięć rozdziałów otwarto, cztery tymczasowo zamknięto), 30 marca 2012 roku (cztery rozdziały otwarto, z których dwa tymczasowo zamknięto), 22 czerwca 2012 roku (otwarto trzy rozdziały), 24 października 2012 roku (otwarto trzy rozdziały), 18 grudnia 2012 roku (otwarto sześć rozdziałów, jeden tymczasowo zamknięto). Do końca 2012 roku jedenaście rozdziałów negocjacyjnych zostało tymczasowo zamkniętych (nauka i badania; edukacja i kultura; swobodny przepływ pracowników; prawo własności intelektualnej; prawo spółek; przedsiębiorstwa i polityka przemysłowa; sieci transeuropejskie; sądownictwo i prawa podstawowe; ochrona zdrowia i konsumentów; polityka zagraniczna, bezpieczeństwa i obronna; polityka konkurencji) (Enlargement).

Na szybkie tempo przebiegu negocjacji akcesyjnych Islandii wpływ miało kilka, wskazywanych już, czynników. Po pierwsze, istotny jest poziom rozwoju gospodarczego państwa kandydującego (wyższy poziom generuje większą zbieżność z gospodarką UE). Po drugie, ważna jest zbieżność prawodawstwa krajowego z prawodawstwem unijnym, którą można osiągnąć dotychczasową ścisłą współpracą z UE (mniejsze rozbieżności powodują sprawniejsze zamykanie rozdziałów negocjacyjnych i brak konieczności negocjowania okresów przejściowych). Po trzecie, wpływ na przebieg rokowań ma międzynarodowa sytuacja gospodarcza i poparcie społeczeństwa dla rozszerzenia - i tutaj odnotowano więc poparcie dla Reykjaviku, który wszelkimi sposobami starał się opanować kryzys gospodarczy.

Finalnym etapem rokowań jest wypracowanie przez obie strony projektu traktatu akcesyjnego, który po uzgodnieniu jest parafowany przez strony - państwa członkowskie oraz państwo kandydujące - podczas ostatniego spotkania międzyrządowej konferencji akcesyjnej. W przypadku Islandii do tego nie doszło, ponieważ w 2013 roku Reykjavik poinformował o wstrzymaniu procesu negocjacji akcesyjnych.

\section{Od wzrostu gospodarczego do rezygnacji}

Biorąc pod uwagę procedurę akcesyjną, złożoną z ośmiu etapów (wniosek o członkostwo w Unii Europejskiej zainteresowanego państwa; opinia wstępna Komisji Europejskiej; przyznanie statusu państwa kandydującego; negocjacyjne akcesyjne; przyjęcie traktatu akcesyjnego; podpisanie traktatu akcesyjnego; ratyfikacja traktatu akcesyjnego; wejście w życie traktatu akcesyjnego) (Barcik, Wentkowska, 2011, s. 45-46), stwierdzić można, iż Islandia zawróciła „w połowie drogi”.

Jeszcze przed zawieszeniem negocjacji analiza zbliżenia (już sobie bliskich) Islandii i Unii Europejskiej wskazywała wiele kwestii, które mogły stanowić poważne bariery dla kontynuacji procesu akcesyjnego. Wymienić należy przede wszystkim:

- prowadzoną przez Islandię politykę zagraniczną, postrzeganą jako skrajnie niezależną; 
- poczucie zagrożenia tożsamości narodowej u niektórych grup społecznych (szczególnie ze względu na fakt, iż Islandia stała się niezależnym państwem dopiero w 1944 roku);

- rozbieżność interesów Islandii i UE w dziedzinie rybołówstwa i rolnictwa;

- wstąpienie do strefy euro, dla którego poparcie spada razem z poprawą wewnętrznej sytuacji gospodarczej Islandii;

- członkostwo w Europejskim Obszarze Gospodarczym i strefie Schengen, dzięki którym obywatele Islandii korzystają z wielu praw przysługujących obywatelom UE, a które nie łączą się z pełnym członkostwem, utratą części suwerenności i kosztami finansowymi;

- spory z państwami członkowskimi UE (m.in. Wielką Brytanią i Holandią) czy o rybołówstwo (Willa, 2013, s. 38-39).

Z kolei w związku z podejmowanymi reformami, poprawiała się sytuacja gospodarcza Islandii, przez co stopniowo zanikała motywacja do dalszych rozmów z Unią Europejską. Wprowadzane zmiany, polegające m.in. na przejmowaniu upadłych banków przez państwo (bez regulacji zobowiązań wobec podmiotów zagranicznych), wykorzystaniu w początkowej fazie kryzysu narzędzi fiskalnych oraz kursu jako automatycznych stabilizatorów koniunktury, restrukturyzacji zadłużenia podmiotów krajowych czy konsolidacji publicznych finansów (Wajda-Lichy, 2013, s. 203), stopniowo odnajdywały swoje odzwierciedlenie w makroekonomicznych osiagnięciach Reykjaviku.

Tabela 3

Gospodarka Islandii w latach 2006-2014

\begin{tabular}{||c|c|c|c|c|c|c|c|c||}
\hline Rok & PKB (USD) & $\begin{array}{c}\text { PKB per } \\
\text { capita } \\
\text { (USD) }\end{array}$ & $\begin{array}{c}\text { PKB } \\
\text { wzrost } \\
(\%)\end{array}$ & $\begin{array}{c}\text { Import } \\
(\% \text { PKB) }\end{array}$ & $\begin{array}{c}\text { Eksport } \\
(\% \text { PKB) }\end{array}$ & $\begin{array}{c}\text { Inflacja } \\
(\%)\end{array}$ & $\begin{array}{c}\text { Dług } \\
\text { publiczny } \\
\text { (\% PKB) }\end{array}$ & $\begin{array}{c}\text { Deficyt } \\
\text { budżetowy } \\
\text { (\% PKB) }\end{array}$ \\
\hline 2006 & 17101040182 & 56293,8 & 4,2 & 48,1 & 31,1 & 4,6 & 43,2 & 6 \\
\hline 2007 & 21446741082 & 68835,3 & 9,7 & 42,1 & 33,4 & 3,6 & 40,9 & 5 \\
\hline 2008 & 17599245766 & 55445,7 & 1,2 & 43,3 & 41,2 & 12,8 & 79,3 & -12 \\
\hline 2009 & 12823849535 & 40263,4 & $-5,1$ & 40,8 & 49,7 & 16,3 & 99,5 & -8 \\
\hline 2010 & 13261035517 & 41696,0 & $-3,1$ & 43,1 & 53,5 & 7,5 & 105,7 & -9 \\
\hline 2011 & 14665793477 & 45972,3 & 2,4 & 48,3 & 56,4 & 4,2 & 113,0 & -5 \\
\hline 2012 & 14182614909 & 44221,7 & 1,3 & 50,6 & 56,7 & 6,0 & 112,6 & -3 \\
\hline 2013 & 15330057867 & 47349,5 & 3,6 & 47,4 & 55,6 & 4,1 & 97,9 & $b / d$ \\
\hline 2014 & 17036097481 & 52426,0 & 1,9 & 47,1 & 53,5 & 1,0 & 94,0 & 0,1 \\
\hline \hline
\end{tabular}

Źródło: Opracowanie własne na podstawie: WorldBank, Data, www.data.worldbank.org, 15.05.2015; European Commission, Eurostat, www.ec.europea.eu/eurostat, 15.05.2015; CIA The World Factbook, Iceland, www.cia.gov/library/publications/the-world-factbook, 15.05.2015.

W kontekście tych wątpliwości, a także zmiany władzy w wyniku wyborów z 2013 roku, kiedy to rządy ponownie objęła koalicja Partii Niepodległości i Partii Postępu (prawicowa PN i centrowa PP uzyskały po 19 miejsc w 63-osobowym islandzkim parlamencie, Althingu), oraz zróżnicowanego poparcia samych Islandczyków dla ściślejszej integracji z Unią Europejską, nie powinna dziwić decyzja z 2013 roku o zawieszeniu negocjacji w sprawie członkostwa Islandii w UE (Islandia dalej). Zwycięskie 
ugrupowania ogłosiły, iż nie zamierzają kontynuować negocjacji akcesyjnych do czasu, aż przeprowadzone zostanie referendum w tej sprawie.

Co więcej, w lutym 2014 roku prezydent Islandii, Ólafur Ragnar Grímsson, twierdził, że „Islandia nie jest dobrze przygotowana do członkostwa w UE z tych samych powodów, co Norwegia i z tych, które doprowadziły do tego, że Grenlandia wycofała się z UE. Członkostwo nie będzie pasowało Islandii z powodu charakteru naszej gospodarki, jak również w związku z lokalizacją" (Islandia nie jest), a do islandzkiego parlamentu wpłynął projekt ustawy dotyczącej wycofania się Islandii z negocjacji akcesyjnych z UE (Islandia niechętna).

Ten fakt, mimo braku poparcia społeczeństwa dla akcesji, wywołał szereg protestów w stolicy kraju. Islandczycy domagali się referendum w sprawie członkostwa w UE, które Partia Niepodległości obiecała w trakcie kampanii wyborczej; przygotowano również petycję, którą podpisało 55 tys. osób - blisko 1/5 liczby ludności państwa. Reakcją na demonstracje było odroczenie wycofania aplikacji Islandii o członkostwo w UE (Islandia jednak).

Jednocześnie trwający impas przerwać próbował ówczesny przewodniczący Komisji Europejskiej, José Manuel Barroso, który twierdził z jednej strony, że „w interesie zarówno UE, jak i Islandii jest to, by decyzja została podjęta po odpowiedniej refleksji, w sposób obiektywny i spokojny”, z drugiej jednak podkreślał, że: „czas ucieka. W interesie obydwu stron jest to, aby decyzja została podjęta bez dalszej zwłoki. Mam nadzieję, że dalsza debata w Islandii pokaże, w którą stronę zmierzamy" (Barroso).

Kwestia islandzkiej aplikacji powróciła z początkiem 2015 roku. Premier Sigmundur Davið Gunnlaugsson, powołując się przede wszystkim na fakt, iż decyzję o aplikacji podjął poprzedni rząd, o odmiennych niż obecne celach politycznych, w dodatku przed zmianami w samej Unii Europejskiej, zapowiedział nieoficjalnie wycofanie wniosku (Islandia rezygnuje). 12 marca minister spraw zagranicznych, Gunnar B. Sveinsson, zakomunikował, iż Islandia nie zamierza wznowić negocjacji akcesyjnych i wycofuje swoją kandydaturę do członkostwa w Unii Europejskiej, jednocześnie podkreślając wagę bliskich relacji i współpracy pomiędzy stronami (Letter). Rzecznik Wysokiej Przedstawiciel UE ds. Zagranicznych i Polityki Bezpieczeństwa, Maja Kocijanczicz oświadczyła, iż decyzja ta została przyjęta do wiadomości, jednak „drzwi do Unii Europejskiej pozostają otwarte dla Islandii” (UE zostawia).

Informacja ta zdecydowanie mniej przychylnie została przyjęta w samej Islandii, prowadząc do kolejnych protestów Islandczyków, oburzonych pominięciem kampanijnej obietnicy przeprowadzenia referendum w tej sprawie i lekceważeniem demokracji. Wątpliwości odnośnie do mocy prawnej listu z 12 marca przedstawiali konstytucjonaliści, a także partie opozycyjne, twierdzące, że decyzja została ostatecznie podjęta nie tylko z pominięciem społecznych konsultacji, ale też z pominięciem parlamentu, czego wymaga prawo w odniesieniu do ważniejszych decyzji z zakresu polityki zagranicznej państwa. „Althing postanowił ubiegać się o członkostwo i tylko Althing może uchylić tę decyzję" - twierdził Árni Páll Árnason, lider socjaldemokratów (Arnarsdóttir, 2015). Niemniej jednak decyzję islandzkiego rządu oficjalnie potwierdził Edgars Rinkēvičs, minister spraw zagranicznych Łotwy, sprawującej prezydencję w Radzie Unii Europejskiej w I półroczu 2015 roku, podkreślając również, iż dalsza współpraca 
jest istotna, szczególnie ze względu na uczestnictwo Islandii w EOG, strefie Schengen i wobec wspólnych działań w obszarze arktycznym (Draft).

$$
* * *
$$

Stwierdzić można, że rozpoczęte negocjacje akcesyjne wpłynęły na zmianę stosunków bilateralnych UE i Islandii, choć w sprawach najbardziej kontrowersyjnych (m.in. rybołówstwo, rolnictwo, swobodny przepływ kapitału) nie udało się nawet wypracować stanowisk negocjacyjnych (Payne, Puka, 2013, s. 1).

Wobec poprawiającej się sytuacji gospodarczej Islandii, która - prócz programowego eurosceptycyzmu obecnej koalicji - miała zdecydowany wpływ na decyzję rządu o zakończeniu procesu akcesyjnego, perspektywa członkostwa tego państwa w Unii Europejskiej jest nikła. Być może dalsze zbliżenie byłoby możliwe, gdyby do władzy powróciły ugrupowania socjaldemokratyczne, niemniej w tej sytuacji decydujący byłby stosunek Islandczyków do akcesji (podzielonych w tej sprawie, jednak protestujących przeciw lekceważeniu własnego prawa do wyrażenia opinii). Niemniej ten nie zmieni się, jeśli rządy będą spełniać obietnice przedwyborcze (zmniejszać zadhużenie gospodarstw domowych), a gospodarka Islandii będzie odnotowywać wzrost. Co trzeba zauważyć - to wsparcie UE dla Islandii pozwoliło wrócić państwu na drogę wzrostu gospodarczego, jednocześnie osłabiając motywację tego państwa w odniesieniu do akcesji (Payne, Puka, 2013, s. 2).

Próby powrotu do status quo sprzed kryzysu z 2008 roku w stosunkach pomiędzy Islandią a Unią Europejską potwierdzają jedynie słabość motywacji Reykjaviku w odniesieniu do członkostwa w UE. Wszelkie decyzje związane ze złożeniem aplikacji i rozpoczęciem negocjacji nie były wyrazem strategicznej reorientacji polityki zagranicznej Islandii, a jedynie doraźnym środkiem ratującym przed skutkami gospodarczej zapaści.

W odniesieniu do tej sytuacji nie sposób nie zastanawiać się też nad przyszłością polityki rozszerzenia Unii Europejskiej i atrakcyjnością członkostwa jako motoru zmian w państwach kandydujących, szczególnie wziąwszy pod uwagę sytuację w strefie euro i przemiany, które obecnie przechodzi Unia.

\section{Bibliografia}

Adamczyk A. (1997), Problem cypryjski, „Studia Europejskie, nr 4, Warszawa.

Arnarsdóttir E. S., Opposition United on EU, „,Treason” Says Foreign Minister, 16.03.2015, IcelandReview.com, www.icelandreview.com/news/2015/03/16/ opposition-united-eu-treasonsays-foreign-minister, 15.05.2015.

Barcik J., Wentkowska A. (2011), Prawo Unii Europejskiej po Traktacie z Lizbony, Wydawnictwo C. H. Beck, Warszawa.

Barcz J. (2009), Unia Europejska. System prawny, porzadek instytucjonalny, proces decyzyjny, Krajowa Szkoła Administracji Publicznej, Warszawa.

Barroso popędza Islandię, 18.07.2013, EurActiv.pl, www.euractiv.pl/polityka-zagraniczna/artykul/ barroso-popdza-islandi-004874, 15.05.2015. 
Boyes R. (2009), Meltdown Iceland. Lessons on the World Financial Crisis from a Small Bankrupt Island, Bloomsbury USA, New York.

Candidate countries and potential candidates: main economic indicators (cpc_ecmain), National accounts (including GDP), Eurostat, www.epp.eurostat.ec.europa.eu, 15.05.2015.

Communication from the Commission to the European Parliament and the Council, Commission Opinion on Iceland's application for membership of the European Union, European Commission, 24.02.2010, SEC(2010) 153.

Conclusions of the Presidency. European Council in Copenhagen 21-22 June 1993, Council of the European Union, SN 180/1/93 REV 1.

Dośpiał-Borysiak K. (2007), Państwa nordyckie a Unia Europejska, Wydawnictwo Sejmowe, Warszawa.

Draft reply to the letter from the Minister for Foreign Affairs of Iceland to the Presidency of the Council, 17.04.2015, Council of the European Union, 7864/15 LIMITE ELARG 16 ISL 4.

Enlargement Countries. Detailed country information - Iceland, European Commission, www. ec.europa.eu/enlargement/countries/detailed-country-information/iceland/index_en.htm, 15.05.2015.

Gibas-Krzak D. (2009), Serbsko-albański konflikt o Kosowo w XX wieku. Uwarunkowania - przebieg - konsekwencje, Wydawnictwo Adam Marszałek, Toruń.

Gudmundsson M. (2011), The Financial Crisis in Iceland: Reflections on causes, consequences and lessons to be learnt, Bank of England, London.

Hreinsson P., Gunnarsson T., Benediktsdóttir S. (2010), Report of the Special Investigation Commission (SIC), Special Investigation Commission, Reykjavik.

Huntington S. (1993), The Clash of Civilizations?, "Foreign Affairs", nr 3, New York.

Iceland. Negotiating Framework - July 2010, European Commission, www.ec.europea.eu, www. ec.europa.eu/enlargement/pdf/iceland/st1222810_en.pdf, 15.05.2015.

Islandia dalej od Unii Europejskiej, 23.08.2013, EurActiv.pl, www.euractiv.pl/rozszerzenie/artykul/ islandia-dalej-od-unii-europejskiej-004948, 15.05.2015.

Islandia jednak w UE?, 13.05.2014, EurActiv.pl, www.euractiv.pl/polityka-zagraniczna/artykul/islandia-jednak-w-ue-005761, 15.05.2015.

Islandia nie jest gotowa na wejście do Unii Europejskiej, 26.02.2014, IcelandNews.is, www.icelandnews.is/wiadomosci/z-kraju/islandia-nie-jest-gotowa-na-wejscie-do-unii-europejskiej, 15.05.2015.

Islandia niechętna integracji europejskiej, 24.02.2014, UniaEuropejska.org, www.uniaeuropejska. org/islandia-niechetna-integracji-europejskiej, 15.05.2015.

Islandia rezygnuje z kandydowania do UE, 13.03.2015, EurActiv.pl, http://www.euractiv.pl/demokracja/artykul/islandia-rezygnuje-z-kandydowania-do-ue-006683, 15.05.2015.

Key figures on the enlargement countries. 2013 edition, Eurostat, www.epp.eurostat.ec.europa.eu/ cache/ITY_OFFPUB/KS-GO-13-001/EN/KS-GO-13-001-EN.PDF, 15.05.2015.

Komunikat Komisji do Parlamentu Europejskiego i Rady, Strategia rozszerzenia i najważniejsze wyzwania w okresie 2006-2007 wraz ze sprawozdaniem specjalnym dotyczacym zdolności UE do przyjmowania nowych państw, Komisja Europejska, COM(2006) 0649.

Konkluzje szczytu Rady Europejskiej z 17 czerwca 2010 r., Rada Europejska, EUCO 13/10.

Kurkliński L. (2010), Bankowość islandzka - bankructwo systemu?, w: Międzynarodowe bankructwa $i$ afery bankowe, red. P. Masiukiewicz, Oficyna Wydawnicza SGH, Warszawa.

Letter from the Minister of Foreign Affairs of Iceland to the Presidency of the Council, 12.03.2015, Ministry of Foreign Affairs, Reykjavik, www.mfa.is/media/gunnar-bragi/Bref-ESB-ENSpdf.pdf, 15.05.2015. 
Muś J. (2011), Integracja Macedonii z Unia Europejska - przebieg, perspektywy i wyzwania, w: Konflikty narodowe i europejskie aspiracje państw bałkańskich, red. M. Filipowicz, Instytut Europy Środkowo-Wschodniej, Lublin.

Osiński J. (2011), Przemiany polityczne na Islandii w warunkach kryzysu bankowego i gospodarczego, Kwartalnik KES „Studia i Prace”, nr 1(5), Warszawa.

Ólafsson S. (2011), Iceland's Financial Crisis and Level of Living Consequences, bjóðmálastofnun - Social Research Centre - University of Iceland, Reykjavik.

Payne D., Puka L. (2013), Stosunki Islandii z Uniq Europejskq: potrzeba partnerstwa, „Biuletyn Polskiego Instytutu Spraw Międzynarodowych", nr 102(1078), Warszawa.

Polityka zagraniczna UE-Islandia: pierwszy krok ku przystapieniu do UE, 28.07.2009, Komisja Europejska, www.ec.europa.eu, www.ec.europa.eu/news/external_relations/090728_pl.htm, 15.05.2015.

Popławski D., Starzyk-Sulejewska J. (2012), Outsiderzy integracji europejskiej. Szwajcaria i Norwegia a Unia Europejska, Wydawnictwo Naukowe SCHOLAR, Warszawa.

Public Opinion. For each of the following countries, are you in favour or not of it becoming part of the European Union in the future? Iceland, 2008, European Commission, www.ec.europa.eu, www.ec.europa.eu/public_opinion, 15.05.2015.

Rezolucja legislacyjna Parlamentu Europejskiego w sprawie instytucjonalnych aspektów zdolności Unii Europejskiej do przyjmowania nowych państw członkowskich, Parlament Europejski, 2006/226 (INI), Dz. Urz. UE C 317 E/485 z 23.12.2006.

Rezolucja Parlamentu Europejskiego w sprawie komunikatu Komisji dotyczacego strategii rozszerzenia i najważniejszych wyzwań w okresie 2006-2007, Parlament Europejski, 2006/2252 (INI), Dz. Urz. UE C 317/E/480 z 23.12.2006.

Skibińska-Fabrowska I. (2013), Rola banku centralnego w czasie kryzysu bankowego na przyktadzie Banku Centralnego Islandii - wnioski dla Polski, „Zarządzanie i Finanse”, nr 2, Gdańsk.

Śmieszek M. (2013), Quo vadis Islandio? O wydarzeniach ostatnich miesięcy na Islandii i ich znaczeniu dla UE, „Komentarze Natolińskie”, nr 2(21), Warszawa.

UE zostawia Islandii otwarte drzwi, 16.03.2015, EurActiv.pl, www.euractiv.pl/instytucje/artykul/uezostawia-islandii-otwarte-drzwi-006688, 15.05.2015.

Wajda-Lichy M. (2013), Lekcje z doświadczeń Islandii w przeciwdziałaniu skutkom kryzysu finansowego, „Zeszyty Naukowe Uniwersytetu Ekonomicznego w Katowicach”, Katowice.

Willa R. (2013), Unia Europejska na arenie międzynarodowej - wybrane relacje bilateralne, Wydawnictwo Naukowe Uniwersytetu Mikołaja Kopernika, Toruń.

World Factbook, Central Intelligence Agency, www.cia.gov/library/publications/the-world-factbook, 15.05.2015.

\section{Streszczenie}

Wobec konsekwencji kryzysu, który wybuchł w Islandii na początku października 2008 roku, najskuteczniejszym rozwiązaniem - wedhug nowego, socjaldemokratycznego rządu wybranego w 2009 roku - prowadzącym do poprawy sytuacji gospodarczej, miało stać się członkostwo w Unii Europejskiej. Artykuł analizuje przyczyny zainteresowania Reykjaviku członkostwem w Unii Europejskiej, mocne i słabe strony kandydatury Islandii (w tym w porównaniu do pozostałych państw kandydujących i potencjalnie kandydujących), a także powody, przez które proces akcesyjny został najpierw zawieszony, a następnie zakończony. Próba podsumowania integracji Islandii z UE została dokonana przede wszystkim na podstawie ram prawno-instytu- 
cjonalnych, które określają procedurę akcesyjną, stany dotychczasowej współpracy pomiędzy stronami, a także dział podejmowanych przez strony od 2009 roku.

Słowa kluczowe: Islandia, kryzys finansowy, proces akcesyjny, polityka rozszerzenia UE, państwa kandydujące

\section{Five years of Iceland's European ambitions - from membership application to the suspension of the accession process}

\section{Summary}

In view of the consequences of the crisis that erupted in Iceland in early October 2008, the most effective solution - according to the new social democratic government elected in 2009 - leading to economic recovery, had become the membership in the European Union. The article analyzes the causes of Reykjavik's interest in accession, the strengths and weaknesses of the Iceland's candidacy (including comparison with the other candidate countries and potential candidates) as well as the reasons for which the accession process was firstly suspended and then - terminated. An attempt to summarize the Iceland's integration with the EU was made primarily on the basis of the legal and institutional framework, which sets out the accession procedure, the level of the existing cooperation between Iceland and the EU and the actions taken by them since 2009 .

Key words: Iceland, economic crisis, accession process, EU enlargement policy, candidate states 
